\title{
Mary Ward's English Institute and Prescribed Female Roles in the Early Modern Church ${ }^{1}$
}

\section{Laurence Lux-Sterritt}

Introduction

Protestantism gained much ground in late sixteenth and early seventeenth-century Europe, prompting the Catholic Church to embark upon a world-wide catechizing endeavour. The reforming Council of Trent (1545-63) sought to respond to the challenges of the rapidly-changing religious picture, giving increased importance to missionary vocations amongst the clergy. However, it made no provision for women religious to become part of this common effort; on the contrary, in 1563, it reasserted that the only acceptable form of religious life for women was cloistered contemplation. Yet before and after Trent, many unenclosed female movements emerged which sought to complement male apostolic movements. Earlier in this volume, Querciolo Mazzonis evoked the vocation of the Italian Angela Merici (1474-1540), whose Company of Saint Ursula combined contemplation and care of one's neighbour. Marit Monteiro's essay also shows that, in the Netherlands, spiritual virgins, or 'beguines', found it difficult to match the usefulness of their active endeavours with the authorities' reticence towards females who escaped traditional status definitions. In France, the Congrégation de Notre-Dame (1597), François de Sales's Visitation (1610-1616) or the Filles de la Charité (1634) all shared the same apostolic essence. ${ }^{2}$ Their main vocation was not the observance of a monastic way of life but rather an evangelical brief which implied constant interaction with others. For England, the main representative of this female apostolic movement was Mary Ward.

\footnotetext{
${ }^{1}$ I would like to thank Claire Cross, Michael Questier, Carmen M. Mangion and Glyn Redworth for their insights and valuable comments on the early drafts of this essay.

${ }^{2}$ See E. Rapley, The Dévotes: Women and Church in Seventeenth-century France (Kingston, Ont.: McGill, Queen's University Press 1990) and R. Liebowitz, 'Virgins in the Service of Christ: The Dispute over an Active Apostolate for Women during the Counter-Reformation', in R. Radford Ruether (ed.), Women of Spirit (New York: Simon and Schuster, 1979), pp. 131-52.
} 
Born at Mulwith near Ripon, in Yorkshire, Mary Ward (1585-1645) became acquainted, from an early age, with missionary activities in recusant networks. She felt called to serve God and, in 1606, she left England to become a Poor Clare in St Omer. Yet taking the veil did not bring her spiritual peace; between 1607 and 1611, she received what she later described as a series of revelations through which God called her to serve Him in a different way. Initially, she could not envisage any religious life outside the convent; in 1607, she left her Flemish convent to found a house of Poor Clares specifically for English women. Finally, in 1611, she received what she described as the divine command to 'Take the Same of the Society': this epiphany prompted her to found a congregation modelled upon the Society of Jesus 'both in matter and manner'. ${ }^{3}$ Within a few years, houses were opened across the Continent, in Liège (1616), in Cologne and Trier (1620-1), in Rome (1622), in Naples and Perugia (1623), in Munich and Vienna (1627) and finally in Bratislava and Prague (1628). In parallel, small clandestine houses also operated in England.

When Mary Ward created her Institute of English Ladies ${ }^{4}$, her purpose was to provide a female counterpart to the male missionaries in England and on the Continent. Yet her dedication to the creation of an independent Society of Jesus for women, combined with the canonical transgressions this entailed, triggered a violent clerical reaction against her proposal. In 1621, the secular clergy wrote a Memorial against the English Ladies; Propaganda Fide began enquiries into their orthodoxy in $1624 .^{5}$ Finally, in 1631, Pope Urban VIII suppressed them with the Bull Pastoralis Romani Pontificis, condemning their

3 Mary Ward described this episode retrospectively in a letter to Mgr Albergati, reproduced in Mary Ward to Nuncio Antonio Mgr Albergati, 1621, in U. Dirmeier, CJ (ed.), Mary Ward und ihre Gründung: Die Quellentexte bis 1645 (Münster: Aschendorff Verlag, 2007), vol.1, pp. 53642.

${ }^{4}$ Since during Mary Ward's lifetime her Ignatian Institute was not given an official name; she and her followers were simply known as 'the English Ladies'.

${ }^{5}$ Founded in 1622 by Gregory XV, the purpose of Propaganda Fide was both to supervise missions to non-Christian regions and to check the spread of heresy. When Mary Ward's endeavours were perceived as unorthodox, possibly even heretical, Propaganda Fide was naturally in charge of the investigations. See M. I. Wetter, Mary Ward: Under the Shadow of the Inquisition 1630-1637 translated by M. B. Ganne and M. P. Harriss (Oxford: Way Books, 2006), pp.54-64. 
vocation and their way of life. ${ }^{6}$ Defeated by clerical opposition, Ward returned to England, where she died in January $1645 .^{7}$

Until recently, most publications on Mary Ward came either from members of her Institute or from supportive clerics. The authoritative biography written by M.C.E. Chambers is a mine of detailed information, but has a marked tendency towards hagiography. Similarly, remarkable studies such as those undertaken by Josef Grisar, SJ, Immolata Wetter, IBVM or Henriette Peters, IBVM were written in the cause for Mary Ward's canonisation. ${ }^{8}$ Because of their nature, these highly valuable sources sometimes neglect the general context which influenced Ward's fate. Yet the most recent publications indicate that this trend may be coming to an end: both Ursula Dirmeier, CJ and Christina Kenworthy-Browne CJ, have taken exciting steps to make the Institute's primary sources available in print, thereby ushering a phase in which Mary Ward's historiography may quickly take new directions. $^{9}$

This chapter seeks to examine the difficulties which led to the suppression of Mary Ward's Institute. Rather than dealing with the Institute's merits or shortcomings per se, it will examine the extent to which Mary Ward's congregation diverged from clericallyimposed norms by comparing her own definition of her vocation (which she gave in her 1622 Plan known as the Institutum $^{10}$ ) with male-filtered expressions of what was

${ }^{6}$ L. Lux-Sterritt, 'An Analysis of the Controversy Caused by Mary Ward's Institute in the 1620s', Recusant History, 25.4 (2001), pp. 636-47.

${ }^{7}$ See M. G. Kirkus, 'The Presence of the Mary Ward Institute in Yorkshire 1642-1648', Recusant History, 25.3 (2001), pp. 434-48.

${ }^{8}$ The two reference works available in English about Mary Ward's life and work are M.C.E. Chambers, The Life of Mary Ward, 1585-1645, 2 vols (London: Burns and Oates, 1882-1885) and H. Peters, Mary Ward: A World in Contemplation, translated by H. Butterworth (Leominster: Gracewing Books, 1994). In German, J. Grisar, Die Ersten Anklagen in Rom Gegen das Institut Maria Wards (Roma: Pontificia Universita Gregoriana, 1959).

${ }^{9}$ The Institute's primary sources are to be found in extenso for the first time in Dirmeier, Mary Ward; see also the work by C. Kenworthy-Browne, CJ CJ (ed.), Mary Ward, 1585-1645: A Briefe Relation with Autobiographical Fragments and a Selection of Letters (Woodbridge: Boydell, 2008).

${ }^{10}$ In 1616, Mary Ward had written her first Plan for the Institute, known as the Ratio Instituti; yet it is her subsequent 1622 Institutum which is recognised as encapsulating most clearly the religious vocation she had received in the 1611 revelation to 'Take the same of the Society'. For that reason, this study will focus upon that version rather than its earlier draft. 
acceptable. Indeed, plans for the approbation of the Institute were written both before and after Ward's own Institutum. The earliest document was drafted by her spiritual director, Roger Lee, SJ (1568-1615), and the Institute he described in his 1612 Schola Beatae Mariae was far removed from Ward's missionary project, offering a more traditional female religious Orders. ${ }^{11}$ The same can be said of the 81 Rules which were finally approved after Frances Bedingfield (1616-1704), once a follower of Mary Ward, took it upon herself to initiate a new phase in the history of the English Ladies. When she purchased houses to be used as centres for priests and elementary schools in Hammersmith (1669) and York (1686), a new Institute was born from the ashes of the old one; yet, in order to seek papal approval, it kept its heritage from Mary Ward carefully hidden. ${ }^{12}$ Its Rules -actively supported by Bishop John Leyburn, Vicar Apostolic of the London District (1685-1702)- were presented in 1699 by the then Chief Superior Mary Anne Babthorpe (d.1711), and gained Clement XI's approbation on 13 June $1703 .{ }^{13}$ What were the elements which made both Lee's Schola and Babthorpe's Rules more likely to gain papal approval than Mary Ward's own Institutum? This chapter will show that the reasons for the Church's condemnation of Mary Ward's vocation stemmed from the missionary nature of that vocation, but also from the institutional form which Ward gave her Institute. Underpinning both, however, was the thorny issue of gender and the prescribed female roles in the early modern Church.

Mary Ward's vocation: unenclosed and missionary

In her 1622 Institutum, Mary Ward emphasized her desire to assist her fellow Catholics and to support her Church. Some aspects of this apostolate remained in keeping with roles deemed acceptable for women, such catechising and educating girls 'in day and boarding

${ }^{11}$ Peters, Mary Ward, pp. 129-31.

${ }^{12}$ H. J. Coleridge (ed.), St Mary's Convent, Micklegate Bar, York, 16861887 (London: Burns and Oates, 1887). The Bar Convent is the oldest operating convent to date in England.

${ }^{13}$ A manuscript of the 1703 Rules is kept in the Bar Convent Archives (hereafter BCA), file J2: Letters Apostolic by which Clement PP. XI, June $13^{\text {th }}, 1703$, approved and confirmed the Rules of the Institute of the Blessed Virgin Mary. 
schools, ${ }^{14}$ Although opening the doors to day pupils and catechizing adults were both relatively new briefs for women religious, such a way of life had been sanctioned by Pope Paul V for the Ursulines of Paris in $1612 .{ }^{15}$ As the example of the so-called 'teaching nuns' was adopted by others, it became part of a movement which witnessed the rapid development of teaching female Orders. ${ }^{16}$ This aspect of Mary Ward's vocation therefore remained within the tolerated sphere of female religious activity.

Nevertheless, the duties of the English Ladies exceeded this traditional brief; in England, they would facilitate the work of missionaries by preparing lay folk for the sacraments and providing spiritual assistance in the absence of priests. They would serve prisoners and attend to the sick; more controversially still, they would 'seek women of doubtful lives' and work for the conversion of those 'estranged from the Church', a role normally recognized as perilous for women. ${ }^{17}$ Mary Ward never envisaged a typical conventual life in her 1622 Institutum; on the contrary, she openly presented her Institute as missionary. Inspired by the Jesuit Formula Instituti and using the same martial vocabulary, she presented her Ladies as crusaders: 'Whoever wishes to serve beneath the banner of the cross as a soldier of God in our Society [...] is a member of a Society founded primarily [...] to strive for the defence and propagation of the faith and for the progress of souls in Christian life and doctrine, leading them back from heresy and evil ways to the faith. ${ }^{18}$ Moreover, the Ladies' mission was to operate on a world-wide level, 'among the Turks or any other infidels, even those who live in the region called the Indies, or among any heretics whatever, or schismatics, or any of the faithful, ${ }^{19}$ Implicitly, of course, they also hoped to work in the English mission, reconquering their native land.

14 BCA: B18, Institutum, item 2. For this essay, I shall use the English translation, kept at the Bar Convent, of the Latin original reproduced in Dirmeier, Mary Ward, vol.1, pp. 625-30.

${ }^{15}$ As Ursuline congregations spread in France and sought papal approval, they adopted conventual enclosure, although they were allowed to receive externs within their walls for their daily lessons. See my Redefining Female Religious Life: French Ursulines and English Ladies in Seventeenth-Century Catholicism (Aldershot: Ashgate, 2005).

${ }^{16}$ Rapley, The Dévotes, pp. 42-73.

${ }^{17}$ BCA: B18, Institutum, item 2.

${ }^{18}$ Ibid, item 1, my italics.

${ }^{19}$ Ibid, f. 22. 
Such a missionary vocation violated the laws of enclosure which had been strictly enforced upon women since the Council of Trent's 1563 decree endorsing Boniface VIII's medieval Bull Periculoso. ${ }^{20}$ In seventeenth-century Europe, the English Ladies were not the only women to denounce the limitations of such a definition of female religious life. Beguines, Ursulines, Visitandines all claimed to play an active part in the on-going mission of Catholic recovery. The Spanish Luisa de Carvajal even claimed a missionary vocation very similar to Mary Ward's, and took an active part in the Catholic mission in England. ${ }^{21}$

Yet although Mary Ward's Institute was part of a broader female movement challenging the Tridentine decrees, it was also unique. Luisa de Carvajal acted as a rogue individual, and her actions remained localized in London. The spiritual virgins and widows of the Low Countries, on the contrary, were legion, and highly visible in their local milieus. ${ }^{22}$ But like Carvajal, they functioned outside religious status; although their endeavours served the Church, they did not claim to be officially part of it. Contrary to Mary Ward, they neither founded multiple branches throughout Europe, not sought papal recognition for an entirely novel female missionary order. The Ursulines did gain official religious status, but this came at the price of their original active vocation, as they gradually moved away from Angela Merici's initially broad apostolic brief and accepted clausura as a teaching religious order for girls. Mary Ward, on the other hand, refused all compromise, but rather hoped to change the Church's views on women's roles as active militants of the Catholic Reformation.

As mentioned earlier, the secular clergy responded to Mary Ward's Institutum with a Memorial addressed to the Pope, in which they denounced the Institute as 'directly contrary

${ }^{20}$ Session 25, 3-4 December 1563, in N. Tanner, Decrees of the Ecumenical Councils, 2 vols (London: Sheed and Ward, 1990), vol. 2, p. 778.

${ }^{21}$ See Rapley, The Dévotes; E. Rhodes, This Tight Embrace: Luisa de Carvajal y Mendoza (1566-1614) (Milwaukee: Marquette University Press, 2000), and 'Luisa de Carvajal's Counter-Reformation Journey to Selfhood (1566-1614), Renaissance Quarterly, 51.3 (1998), pp. 887-911; also G. Redworth, The She-Apostle: The Extraordinary Life and Death of Luisa de Carvajal (Oxford: Oxford University Press, 2008). The difficulties of reconciling action and contemplation and to serve the Church whilst not fully complying with its precepts on female religious life continued to encumber the efforts of nineteenth-century active women religious, as Carmen M. Mangion shows later in this volume.

${ }^{22}$ See Marit Monteiro's chapter in this collection. 
to the decrees of the Sacred Council of Trent'. Although the authors recognized the Ladies' teaching work as worthy of praise, they insisted that these teachers could not be considered religious if they remained unenclosed. ${ }^{23}$ Later, in October 1622, the English secular priest John Colleton ${ }^{24}(1548-1635)$ wrote:

If [the Institute] abode within its cells and walls, after the example of other religious communities, [it] would perhaps deserve much praise, but when it claims the duties of the apostolic office, wanders unrestrainedly about hither and thither $[\ldots]$ and in spite of this insists on being numbered amongst the religious communities, [it] is certainly exposed to the censures and reproaches of many pious people. ${ }^{25}$

The Ladies' geographical mobility was interpreted as symptomatic of their rebelliousness. In the same year, Fr. John Bennet, (d. 1623) the agent for the English secular clergy in Rome, summarized the situation: 'Briefly closure they must embrace, and some Order already approved, or else dissolve. But of closure they will not hear. ${ }^{26}$ Pope and clergy alike perceived Mary Ward's missionary vocation as a threat to Catholic institutions, since it openly advocated an alternative to the only female religious life heretofore recognized.

Mediated expressions of Mary Ward's vocation: an enclosed teaching order

If Mary Ward's own expression of her vocation was controversial, the texts written before and after the Institutum under (male) clerical guidance left more room for compromise. Before the foundress wrote her own plans, her spiritual director Roger Lee, SJ, had cast a first draft in 1612, the Schola Beatae Mariae. Long after Mary Ward's death in 1645, when the 'second Institute' developed by Ward's friend and follower, Frances Bedingfield, sought approval of its Rules, it presented a profile which was closer to Lee's

${ }^{23}$ Westminster Diocesan Archives (henceafter WDA), vol. 16, f. 206.

24 John Colleton formed the Association of the Clergy of England, an independent body in charge of regulating the affairs of the secular clergy. He was later suspended for aggravating the schism between the seculars and the Society of Jesus. See E. Taunton, The History of the Jesuits in England, 1580-1773 (London: Methuen, 1901), pp. 256-57.

${ }^{25}$ BCA: C1, Translation of Documents re. Jesuitesses, J3.

${ }^{26}$ John Bennett to Edward Bennett, in Dirmeier, Mary Ward, vol.1, p. 659. 
Schola than to Ward's missionary order. Both documents downplayed the women's agency and emphasized their compliance with Tridentine decrees. They described Institutes which focused primarily upon the spiritual welfare of their own members through contemplation and prayer, and whose only active brief was the teaching and catechising of girls and women.

As Roger Lee strove to ensure a positive reception for the Institute, he presented its vocation with the vocabulary of modesty and deference suited to all religious, and to women in particular; he described the aim of the institute as follows: 'Firstly, that $[\ldots]$ we may make timely provision for our own salvation by a complete renunciation of the world: Then in accordance with the capacity of our own sex we may devote ourselves to the Christian education of maidens and girls whether outside or inside England'. ${ }^{27}$ Lee chose to comply with conventual tradition: like other women religious, his Ladies sought the advancement of their own souls through detachment from the world and dedication to God. Gendered roles were respected also, since the Ladies' teaching brief was limited to their 'own sex', never venturing into the sphere of male activities and responsibilities. To all intents and purposes, his proposed institute resembled the French Ursulines, who, by then, had become an enclosed order of teaching and catechising nuns. In fact, throughout the years of controversy in the 1620 s, various clerics recommended that the Institute should adopt the Ursuline rules; yet Mary Ward refused to compromise the global missionary nature of her vocation and found such suggestions unpalatable, answering: 'If God give health, we shall find another way to serve him than of becoming Ursulines. ${ }^{28}$

When comparing Lee's Schola to Ward's Institutum, it appears that the cleric negotiated the politics of religion more subtly than his penitent. He knew that women's place in the Church was defined by the male hierarchy which determined standards of acceptable female behaviour. Tellingly, Lee utilized the trope of female humility in a way which is reminiscent of Teresa of Àvila's rhetoric. Alison Weber showed how Teresa's recognition in the Church owed much to her 'pragmatic stylistic', in which seemingly endorsed the

${ }^{27}$ BCA: B18, Schola Beatae Mariae, item 5, italics mine. For this essay, I shall use the English translation, kept in the Bar Convent, of the original Latin document reproduced in Dirmeier, Mary Ward, vol.1, pp.171-84.

${ }^{28}$ Mary Ward to Elizabeth Cotton and Mary Poyntz, 18 February 1631. In Dirmeier, Mary Ward, vol.3, p. 165. 
patriarchal definition of female abilities, the better to gain the trust of clerical sceptics. ${ }^{29}$ Echoing Teresa's strategy, Roger Lee's prose constantly highlighted the 'littleness' of the English Ladies; the Plan was presented as a plea in which they 'begged' to be allowed to 'render services'. Their vocation, described in an almost apologetic fashion, was shown as a mere 'pious desire' to help the Church. The opening paragraph set the tone by suggesting, in the meekest of terms, that the Catholic crisis in England and in Europe called for a reassessment of female involvement, advancing that 'it seem[ed] right that, according to their condition, women also should and c[ould] provide something more than ordinary in the face of this common spiritual need ${ }^{30}$ It was not by chance that Roger Lee chose to conclude this paragraph on typically female virtues likely to meet with the clergy's approval: 'But let them specially strive to be outstanding in humility and meekness'. ${ }^{31}$ In his Schola, not unlike Teresa of Àvila in the Book of Her Life, utilized gendered clichés the better to achieve his goals; such pragmatic compromise was, however, entirely absent in Mary Ward's own Institutum.

Contrary to Mary Ward, Roger Lee also realized that female enclosure was not a condition which could be breached. The Continental houses of the Institute were to be cloistered, while in Protestant England, where houses could not function openly as convents, monastic enclosure would be relaxed only to avoid detection. Yet Lee worded this request carefully:

And although this Institute, of its nature, does not allow of the strict cloister in the present condition of England, still, far from having the house open to all, we desire rather to have cloister so strictly observed that no access is to be allowed to any extern whatsoever in the chapel and schools [...]. But necessary and serious conversations will be

${ }^{29}$ A. Weber, Teresa of Àvila and the Rhetoric of Femininity (Princeton, NJ.: Princeton University Press, 1990) and 'Little Women: Counter-Reformation Misogyny', in D. Luebke (ed.), The Counter-Reformation: The Essential Readings (Oxford: Blackwell, 1999), pp. 143-62.

${ }^{30}$ BCA: B18, Schola, item 1.

${ }^{31}$ Ibid, item 46, italics mine. 
referred to the grille destined for that purpose, and no one shall go without permission of the Superior who shall be present at the conversation $[\ldots]^{32}$

Even as the Schola proposed a Catholic order of women which would function both on the Continent and in Protestant England, it remained tentative in its attitude to enclosure or the evocation of an active apostolate.

The similarity between Roger Lee's 1612 Schola Beatae Mariae and the 81 Rules which obtained papal approval in 1703 is most striking. It is as though the new Institute had used Lee's Schola rather than Ward's Institutum as its model, highlighting contemplation, prayer and the spiritual salvation of its own members, while mentioning the education of girls only in second place: 'The end of this Rule is to enable us to work out, with the grace of God, our own perfection and salvation, and aided by the same Divine grace, to labour for the perfection and salvation of our neighbour, by means of the education of children of our own sex ${ }^{33}$ Quite contrary to Mary Ward's explicit wish, but in keeping with Lee's proposal, the new Institute's active vocation was limited to the instruction of girls, to the exclusion of any missionary ambition. The 81 Rules also echo the Schola on the issue of enclosure: contacts with the outside were to be limited and supervised at the grille; all letters were checked, and correspondence should not be smuggled in or out by externs. Private conversations with day pupils were also to be punished. ${ }^{34}$ The same provisions were made to observe in England a modus vivendi which was as close to cloistered life as possible.

Yet as the Congregation of the Council of Trent examined Mary Anne Babthorpe's petition for the approval of the new Institute, they noted that it breached strict monastic enclosure, since it undertook the education of both boarders and externs and also functioned in England, where clausura was impossible. Its slight adaptation of enclosure therefore denied the new Institute any official religious status. This objection was overcome only when the Ladies argued that they did not request approbation as a religious order in the Church, but merely as a devout congregation of pious women, whose work carried papal

\footnotetext{
${ }^{32}$ Ibid, Schola, item 14, my italics.

${ }^{33}$ BCA: J2, Letters apostolic, f. 12, item 1.

${ }^{34}$ BCA: J2, Rules, p.28-9, items 43-7.
} 
endorsement. ${ }^{35}$ Although it was a clear departure from Mary Ward's intentions, such a compromise represented a first step towards official recognition.

Moreover, Mary Anne Babthorpe recognized that women's spiritual endeavours could succeed only with clerical support, and she had gained strong clerical allies. Bishop John Leyburn, Vicar Apostolic of the London District (1685-1702) supported her appeal in a letter addressed to the Pope, in which he underlined the orthodoxy of those 'noble virgins' ${ }^{36}$ By presenting an unassuming profile, complying with male-defined female religious roles and publicizing its acceptance of episcopal guidance, the new Institute secured the approbation of its 81 Rules in less than four years. ${ }^{37}$

Thus, the 1612 Schola and the 1703 Rules presented only a few differences from female religious orthodoxy and proposed an order which was more likely to obtain papal assent than that presented by Mary Ward in her 1622 Institutum. Indeed, both depicted a congregation which was strikingly similar to that of the French Ursulines, who had reconciled teaching and enclosure in a teaching Order officially confirmed in Paris in $1612 .^{38}$ It is possible that, aware of the developments in religious and apostolic life in Europe, Lee and Babthorpe had decided to propose an Institute which, though not entirely faithful to the missionary ideal of Mary Ward, might be better attuned to the definition of female roles in the post-Tridentine Church.

Yet it was not only Mary Ward's active vocation which had been at the core of the virulent debate leading to the Institute's suppression in 1631; her proposed unenclosed mission was novel in itself, but it became all the more dangerous in the context of the dispute between Jesuits and secular clergy, and particularly in the English context where secular priests and Jesuit missionaries were in open conflict. Thus, the fact that Mary Ward chose to model her congregation on the Society of Jesus played a crucial part in the condemnation of her Institute.

${ }_{35}^{35}$ Coleridge, St Mary's Convent, pp. 106-7.

${ }^{36}$ London, 16 October 1699; letter reproduced in Coleridge, St Mary's Convent, p. 106.

${ }^{37}$ Mary Anne Babthorpe had begun petitioning in Rome in 1699.

${ }^{38}$ For a more detailed comparison of Mary Ward's Institute with the Order of the Ursulines, see my Redefining Female Religious Life, and A. Conrad, Zwischen Kloster und Welt: Ursulinen und Jesuitinnen in der katholischen Reformbewegung des XVI-XVII. Jahrhunderts (Mainz: Von Zabern 1991). 
Institutional Issues: Mary Ward's Female Society of Jesus

Mary Ward claimed that her definition of the Institute was not a personal choice, but rather an act of self-surrender to God's commandment to Take the Same of the Society'. She therefore adopted both the vocation and the hierarchical structure used by the Society of Jesus, which gave unprecedented levels of autonomy to her English Ladies. Internally, all the branches of the Institute were coordinated by one central figure, the Mother Superior General, who fostered a unity of rule and governance between all the houses across Europe and England. ${ }^{39}$ This organisation in a generalate departed radically from the norm of female religious Orders and was highly controversial, especially since the Superior General's authority was second only to that of the Pope.

Indeed, the foundress requested that the Institute bypass all clerical authority, and make a vow of direct obedience to the Pope. ${ }^{40}$ In her Memorial addressed to Pope Gregory XV in December 1621, she explained why her Institute, unlike traditional female Orders, should not be subject to clerical supervision: '[religious life under episcopal control], though holy in itself and helpful to other religious communities [is] not only contrary to the Institute allotted unto us, but would moreover [...] much molest and hinder us [in] the service we are to perform towards our neighbours'. ${ }^{41}$ Despite the formulaic lip-service paid to the tradition of episcopal control, Mary Ward associated submission to bishops with a hindrance, an impediment which would interfere with the Institute's functioning and violated its vocation. The English Ladies requested self-government and wished (in addition to the customary three vows) to take a fourth vow of direct obedience, recognizing the pope as their only authority outside the Institute's Mother Superior General.

Clerics were incensed by what they perceived as a woman's presumption to dispense with male jurisdiction altogether. In the controversy which escalated in the $1620 \mathrm{~s}$, the English Ladies were repeatedly accused of usurping male privileges; more specifically, Mary Ward was accused of founding a female Society of Jesus. Many of the objections voiced in the 1621 Memorial of the secular clergy addressed this particular issue; the Ladies were labelled 'Jesuitesses', a term which showed that they misconstrued the

${ }^{39}$ BCA: B18, Institutum, item 4.

${ }^{40} \mathrm{Ibid}$, item 7.

${ }^{41}$ Memorial to Gregory XV, in Dirmeier, Mary Ward, vol.1, pp. 597-600. 
Institute's imitation of the Society of Jesus for some sort of assimilation into the Ignatian fraternity. ${ }^{42}$ Although they may well have objected to unenclosed female orders, these clerics were also taking a political stand when they condemned Mary Ward's imitation of the Society of Jesus.

Mary Ward's battle for papal recognition was caught in the cross-fire of the bitter internal fight which opposed the secular clergy to the Jesuits; her handling of this issue demonstrates that she had not fully comprehended the seriousness of the dispute which was tearing the fabric of the Church asunder. Far from realising that her vindication of the Jesuit model was probably her most hazardous argument, she saw in this spiritual affiliation a convincing model. In her correspondence with the Curia, she argued that the Society of Jesus had created a favourable precedent when it was recognized by Paul III in 1540. At a time when the Church needed every advantage it could summon, a congregation of women working to catechize the female half of the population would represent a formidable asset. Mary Ward knew that the Society was not allowed to take the direction of a female order, but did not consider this as a difficulty since her own Society was to be fully autonomous. Her Ladies' independence was a point upon which she insisted in her 1621 Memorial to Gregory XV: she described her Institute as modelled on the Constitutions of the Jesuits, yet 'altogether independent, nevertheless, of the said Fathers'. ${ }^{43}$ In this memorial, Mary Ward attempted to clarify her Institute's independence from the Society of Jesus, thereby denying that it was an unlawful branch of the Society. Her Ladies would be faithfully like Jesuits, yet not a part of Ignatius Loyola's Society of Jesus.

Despite opposition to her project, she was unwilling to compromise on the terms of her mission; the vision she claimed to have received in 1611 had called for a female counterpart to the Society of Jesus and she had no intention of departing from this in any way. ${ }^{44}$ She therefore also demanded that her Institute be named after Jesus: 'Whoever wishes to serve beneath the banner of the cross as a soldier of God in our Society, which we desire to be

\footnotetext{
${ }^{42}$ WDA: vol. 16, ff. 201-207.

${ }^{43}$ Memorial to Gregory XV, in Dirmeier, Mary Ward, vol. 1, pp. 597-600.

${ }^{44}$ Mary Ward to Nuncio Antonio Mgr Albergati, 1621, in Dirmeier, Mary Ward, vol. 1, pp. 536-42.
} 
designated by the name of Jesus $[\ldots] .{ }^{45}$ By using the terms 'Society' and requesting the name of Jesus, Mary Ward proposed nothing less than her own Society of Jesus, adapted for women. This, of course, greatly contributed to the erroneous but nevertheless widespread amalgamation of the English Ladies with the Jesuits. In the context of the bitter dispute which opposed seculars and Jesuits, this was to throw countless difficulties in the path of the Institute.

If the English Ladies faced the opposition of the secular clergy, they also provoked reactions within the Society of Jesus itself. ${ }^{46}$ From the very beginnings in 1612 , the General of the Jesuits, Claudius Aquaviva (1543-1615), had received warnings from alarmed brethren concerned that their Society would be accused of protecting a female branch, in breach of their founder's recommendations. The General had ordered the Jesuits of St Omer to hand over the direction of the Institute to the secular clergy; their only contact with the Ladies of St Omer should be in church, to hear the confessions of those who asked for a Jesuit confessor, in the same way as was customary with any other women.

In the context of the English mission, Mary Ward's enthusiastic imitation and support of the Jesuits was a source of deep embarrassment for the Society, and exacerbated the secular clergy's animosity. As a consequence, most Jesuits detached themselves publicly from the female congregation. The stigma endured and, in 1623, the Provincial Richard Blount (1565-1638) addressed his brethren thus:

[you should] not meddle with any thing belonging to the temporals of Mrs Mary Ward, or any of her company $[\ldots]$ and make the world know that the Society has no more to do with them than with all other penitents who resort unto them, whereby I hope in, a short time, the manifold calumniations, which for their cause and proceedings are laid upon us, will have an end. ${ }^{47}$

${ }^{45}$ BCA: B18, Institutum, item 1. Italics mine.

${ }^{46}$ Peters, Mary Ward, p. 123. See also comments in Wadsworth, James, English Spanish Pilgrim (London: Michael Sparke, 1629), p. 30: '[The Jesuits] are grown to a faction about the Jesuitrices or Wandering Nuns, some allowing them, some disliking them utterly'.

47 Provincial Richard Blount SJ to the English Province, 19 July 1623, in Dirmeier, Mary Ward, vol. 2, pp.3-4. 
Above all, the Fathers should make it quite clear that their Order had no more particular link with these women than they did with other penitents. The few priests who had supported the Ladies, such as Roger Lee himself, but also John Gerard (1564-1637) or Edward Burton (d. 1624), incurred reprimands from their superiors. Slander had thus left a deep scar in the relationship between English Ladies and the Society they so admired, as Jesuits were anxious to dissociate themselves from the so-called 'galloping girls'. ${ }^{48}$

An institutional compromise: a Marian congregation for women

In this context, Roger Lee's early defence of Mary Ward's unenclosed female order had been risky. His Schola Beatae Mariae demonstrates his political acumen, as he attempted to distance Loyola's Society of Jesus from the Ladies' Institute while remaining steadfast in his support to Mary Ward:

Among those Orders [the English Ladies] should specially look to those which most resemble the Institute amongst which not the last is the Society of Jesus [...]. And although from its Institute it cannot undertake the direction of women, it is, however, lawful for all the faithful to be present at their sermons, to confess to them and to profit by their excellent advice. $^{49}$

In this passage, Roger Lee openly recognized that Ignatius Loyola had excluded women from his Society, and that no female branch of the Society of Jesus could be envisaged; having acknowledged this key principle, he emphasized the informal nature of the relationship between Jesuits and Ladies. Although he evoked some links of affinity between the two congregations, he downplayed any special relationship. As a further argument in his favour, he evoked the pragmatic reality of work on the Continent, where the English Ladies found few opportunities to have contact with English-speaking priests, and would therefore naturally attend the services of English Jesuits. As he argued for a continued collaboration between English Ladies and Jesuits, he chose to overlook their shared Rules or ideology, and brushed aside any political connivance in order to highlight harmless practicalities.

48 WDA: vol. 16, f. 207

${ }^{49}$ BCA: B18, Schola, item 48-9. 
Moreover, as Roger Lee portrayed a congregation which did not present a profile modelled on the Society of Jesus, he silenced Mary Ward's unabashed claims for female authority in the form of a generalate and her refusal of episcopal authority, which he replaced with a more traditional subjection to male authority. The Institute was to be placed under episcopal control, and its members' willing obedience was emphasized throughout: '[they] make the three Solemn Vows in the hands of the Bishop, who shall be their Ordinary, to whom they shall with a complete self-oblation bind themselves by vow to the service of God in the education of maidens and girls. ${ }^{50}$ The issue of name was also circumvented. Lee proposed a simple 'School' of virgins placed under the protection of the 'Blessed Virgin Mary', and called after her; Mary Ward's desire for a 'Society' named after 'Jesus' was not expressed, thereby avoiding any misapprehension of the English Ladies as 'Jesuitesses'.

Lee's version of female obedience and organization eventually proved more fruitful than Mary Ward's: it was echoed in the 1703 new Institute's willing submission to episcopal authority. As mentioned earlier, Mary Anne Babthorpe's petition was aided greatly by Bishop Leyburn, who in turn mentioned the support of other Bishops in his address to Clement XI: 'One thing only, most Holy Father, seems in the eyes of not a few, to be wanting to the perfection of this pious work, namely that the said Institute, so lauded by several Bishops, and welcomed into their dioceses, should by your Holiness be deemed worthy of approbation and confirmation'. ${ }^{51}$ Validation from local (secular) ecclesiastical authorities weighed heavily in favour of the petitioners. This proved that the new Institute was in keeping with male definitions of female religious roles; but equally as importantly, it also showed that, politically, the new Institute had no suspicious affiliations with the Society of Jesus. Where Lee's Schola merely recognized the authority of bishops (while

${ }^{50}$ BCA: B18, Schola, item 8.

${ }^{51}$ Coleridge, St Mary's Convent, p. 106. 
being championed by a Jesuit), the new Institute also boasted influential episcopal patronage; thus, it left the perilous waters of political controversy and came back to the fold of religious orthodoxy.

Although neither the 1612 Schola Beatae Mariae nor the 1703 Rules were true expressions of Mary Ward's vocation to 'Take the Same of the Society', there remained a point which they would uphold: both preserved her desire for unity. In 1612, as the idea of multiple foundations was raised, the office of 'Principal', acting as overseer and coordinator of all the houses, was evoked. In the Schola, this was perhaps the only element which was not typical of contemporaneous female orders and gave the virgins an unusual degree of authority. Aware of the bold nature of this innovation, Roger Lee made no mention of a Superior General, whose title was not deemed acceptable for female Orders and remained the preserve of male congregations. In his proposal, the Mother in charge of the global overseeing of the Institute was to be called simply 'Principal', and her role was akin to that of a mother.

Dominating this rather informal, maternal authority, the Ordinary embodied official Church supervision; he was the representative of male clerical hierarchy, whose approval was to be sought before the 'Principal' could undertake her duties. Roger Lee may have realized that the office of Superior General could only hinder the Institute's approval and therefore toned down his request; he diffused the potentially offensive novelty of the post of 'Principal' by not calling it 'Superior General' and by placing it under the supervision of an accepted male authority figure.

The very same issue arose again during the examination of the Rules of the new Institute in the eighteenth century, and was resolved in a similar manner: the petitioners highlighted the fact that each house was under the control of the local bishop, and argued that their own 'Chief Superior' enjoyed a power which was purely maternal, since she simply acted as the Mother of her scattered religious family. Their emphasis upon male authority and their denial of any female empowerment within the hierarchy of the new Institute played a part in the successful approbation of the 1703 Rules, even if like Roger Lee's 1612 Schola, they represented a significant departure from the original spirit of Mary Ward's foundation. 
It would be dismissive to claim that Mary Ward was unaware of the difficulties she faced when proposing a missionary Society of Jesus for women which operated as a generalate, made a direct vow of obedience to the Pope and bypassed bishops' authority; as a Catholic in early-modern England, she was aware of the female religious standards of her time, and she knew also about the controversy which opposed Jesuits to seculars. In 1617, she exhorted her sisters to show the fortitude of pioneers when she declared: '[ $\ldots]$ men you know look diversely upon you as new beginners of a course never thought of before, marvelling what you intend and what will be the end of you'. ${ }^{52}$ Yet she ignored these obstacles and strove to see her vocation approved as she believed God intended; it is in this refusal to compromise that the major difference between her Institutum and the mediated plans which were the 1612 Schola and the 1703 Rules is to be found.

In the seventeenth century, Mary Ward had refused to walk the tightrope of gendered acceptability. Her vindication of female worth in the Catholic mission not only came as a blow to the Church hierarchy but presented a challenge to the received traditional order. Responding to a Jesuit who, in 1617 , doubted the constancy of the religious fervour of those he called 'but women', Mary Ward wrote: 'There is no such difference between men and women, that women may not do great matters, as we have seen by the example of many Saints who have done great things, and I hope in God it will be seen that women in time to come will do much, ${ }^{53}$ As the next passage demonstrates even further, Mary Ward did not share the patriarchal views of the early modern Church:

What think you of this word, 'but women'? If we were in all things inferior to some other creature, which I suppose to be men, which I care be bold to say is a lie then, with respect to the good Father, I may say: it is an error. [...] I would to God that all men would understand this verity: that women, if they will, may be perfect, and if they would not make us believe we can do nothing, and that we are but women, we might do great matters. ${ }^{54}$

${ }^{52}$ Three speeches of our Reverend Mother Chief Superior made at St Omer having been long absent, third speech, in Dirmeier, Mary Ward, vol. 1, pp. 362-6.

${ }^{53}$ Ibid, first speech, in Dirmeier, Mary Ward, vol. 1, pp. 358.

${ }^{54}$ Ibid, p. 359. 
By asserting that 'women, if they will, may be perfect', Ward rejected her contemporaries' conceptions of gender and claimed that, when they were inspired by God and dedicated to Him entirely, women were as capable as men of serving the Church. Yet Mary Ward was not the only foundress not to accept the patriarchal beliefs which marked women as spiritually inept; before her, Teresa of Àvila had argued that, when filled with God's grace, women were spiritually as worthy, perhaps even more so, than men. Yet there was one major difference between May Ward's and when Teresa of Àvila's vindication female religious worth: Teresa expressed her unorthodox ideas through the very orthodox rhetoric of female subjection and inferiority, as a 'little woman' whose ignorance allowed her the better to be filled by the holy spirit. ${ }^{55}$ In doing so, she complied with a medieval exalted definition of women as 'empty vessels', elevated above themselves by God's light. ${ }^{56}$ Mary Ward, on the contrary, remained assertive through her actions and her prose: where Teresa used gender prejudices subtly, she rejected them openly. To her, divisions of gender were not relevant to spiritual life and served only to hinder the efforts of the Catholic Reformation. ${ }^{57}$ Her failure to see the relevance of gender boundaries was going to prevent Mary Ward from enjoying the same degree of success as Teresa of Àvila.

Conclusions

For its opponents, Mary Ward's order was unacceptable: it claimed religious status but chose to follow a male apostolic life, whose missionary activities flouted every Tridentine decree concerning women religious. Faced with such a novel and androgynous enterprise, clerical authorities acted to restore order and reassert their definition of female acceptability in the Church. Urban VIII's Bull Pastoralis Romani Pontificis ordered the English Ladies to disband, since their work was 'most unsuited to the weakness of their sex' and represented a danger for the reputation, the organization, and the sound doctrine of the Catholic Church. The Pope condemned this 'sect' which mimicked 'the customary religious life' despite flouting the laws of enclosure. The Ladies' work was 'by no means

${ }^{55}$ Weber, Teresa of Avvila, p.37.

${ }^{56}$ C. Atkinson, "Precious Balsam in a Fragile Glass": The Ideology of Virginity in the Later Middle Ages', Journal of Family History, 8.2 (1983), pp. 131-43.

${ }^{57}$ P. Ellis, '" They are but women »: Mary Ward, 1585-1645', in S.M. Brown (ed.), Women, Gender and Radical Religion in Early Modern Europe (Leiden: Brill, 2007), pp. 243-64. 
suiting the weakness of their sex, intellect, womanly modesty and above all virginal purity'. Finally, they were labelled 'Jesuitesses'. A canonical aberration which could not be suffered to endure, the Institute was especially abhorrent in the context of the English mission since, through its imitation of the Society of Jesus and its open irreverence towards the secular clergy, it served as a reminder that the Catholic Church was politically divided.

The Institute was condemned to 'perpetual abolition'. ${ }^{58}$ Mary Ward's non-conformity with traditional female role-definitions had been a crucial bone of contention between the foundress and the Church she aimed to serve, and it had led to the suppression of her work. Of course, the Institute was condemned both on religious and political grounds, yet above all, it was suppressed because it was the gendered expression of a female free agent who chose to disregard the criteria of a male-defined orthodoxy. Despite the suppression, Ward's mission was kept alive, though her followers usually opted for a less confrontational stance. Compliance with clerically-defined female roles was indeed the key to Pope Clement XI's 1703 approbation of the 81 Rules of the second Institute which, like Roger Lee's 1612 Schola, closely imitated traditional female religious life. Compliance with gendered norms was, in the end, the only way to gain the approbation of male Church authorities. By respecting some enclosure, accepting episcopal authority, and limiting its activities to the teaching of boarders and externs, this community was in conformity with the clerically-accepted roles for women in the Church; moreover, it showed no particular link with the Society of Jesus and therefore was no longer an element of political controversy. Thus, when the Institute of the Blessed Virgin Mary (IBVM) was confirmed in April 1749, by Benedict XIV's Constitution Quamvis Justo, it bore, on paper, no relation to Mary Ward's earlier foundation.

The history of the Institute remained a complex one through subsequent centuries, and lies beyond the scope of this brief essay; yet some outcomes can be highlighted here, which show the extent to which Mary Ward's vocation to 'Take the same of the Society' had been ahead of its time. Indeed, it was only in the twentieth and twenty-first centuries, after decades of efforts by members and supporters of the Institute, that it became gradually accepted as the true spirit of the IBVM: the initial breakthrough came when, in 1909, Pope

\footnotetext{
${ }^{58}$ Wetter, Mary Ward, pp. 213-14.
} 
Puis X rehabilitated Mary Ward as the original foundress of the IBVM and recognized the value of her militant work. Later, from 1953 onwards, Immolata Wetter and Edelburga Eibl, IBVM, worked indefatigably alongside Josef Grisar, SJ, for the cause of the canonisation of Mary Ward, researching the Institute's history and gaining unprecedented access to the archives of the Inquisition. It was only in June 2003, after continued efforts from the IBVM sisters, that the Roman branch of the $\operatorname{IBVM}^{59}$ was allowed to adopt Ignatian Constitutions, the text of which was feminized, omitting nothing except passages referring specifically to priestly ministries. After nearly four hundred years, members of the IBVM were finally given the right officially to be called the Congregation of Jesus (CJ) and to adapt, in a way which Mary Ward would have recognized as faithful to her original vocation, the rules of the Society of Jesus for the use of women.

59 Since the mission of the sisters expanded worldwide, the IBVM was divided into three (Roman, Irish, and North American) Branches. In 2003, the North American and Irish Branches united to form the Loretto Branch, which is currently transforming, like the Roman Branch, into a female Congregation of Jesus. 